\title{
PENDUGAAN PROPORSI RUMAH TANGGA MISKIN TINGKAT DESA DI PROVINSI BALI DENGAN METODE EMPIRICAL BEST LINEAR UNBIASED PREDICTION DAN BAYESIAN
}

\section{Estimation of Proportion of Rural Poor Households in Bali Province with Empirical Best Linear Unbiased Prediction and Bayesian Methods}

\author{
I. K. G Sukarsa ${ }^{1 *}$, I. G. K Gandhiadi ${ }^{2}$ \\ ${ }^{1,2}$ Program Studi Matematika FMIPA Universitas Udayana \\ Kampus Bukit Jimbaran Badung, Bali, Indonesia
}

Corresponding authore-mail: ${ }^{1 *}$ gedesukarsa@unud.ac.id

\begin{abstract}
Abstrak
Kebijakan pengentasan kemiskinan pada pemerintahan presiden Ir. H. Joko Widodo dilakukan melalui empat strategi kunci yang salah satunya adalah pemberdayaan kelompok masyarakat miskin. Ketersediaan informasi mengenai kemiskinan sangatlah minim padahal untuk menerapkan strategi kebijakan tersebut seharusnya dimulai pada kelompok masyarakat terkecil yakni masyarakat desa. Guna memperoleh informasi kemiskinan pada tingkat desa, penelitian ini menerapkan metode pendugaan area kecil sebagai akibat kurang efektifnya pendugaan langsung pada area kecil. Metode pendugaan area kecil yang umum digunakan yakni metode empirical best linear unbiased prediction (EBLUP), empirical Bayes (EB), dan metode hierarchical Bayes (HB). Hasil yang diperoleh pada pendugaan area kecil pada tingkat desa di Provinsi Bali menujukkan bahwa dugaan proporsi rumah tangga miskin di tingkat desa di Provinsi Bali berada di antara 0,00423 dan 0,03910 serta nilai mean square error yang berada di antara 0,0013 dan 0,1291 diperoleh melalui metode hierarchical Bayes, kemudian untuk metode empirical Bayes diperoleh dugaan proporsi rumah tangga miskin di antara 0,00423 dan 0,03909 serta nilai mean square error di antara 0,0011 dan 0,1288 dan metode empirical best linear unbiased prediction diperoleh dugaan proporsi rumah tangga miskin berada di antara 0,00425 dan 0,03910 serta nilai mean square error di antara 0,00010 dan 0,1291. Secara umum nilai mean square error berada di kisaran yang sama. Sehingga ketiga metode pendugaan tidak dapat disimpulkan yang lebih baik satu dengan yang lainnya.
\end{abstract}

Kata Kunci : Area kecil, empirical Bayes, empirical best linear unbiased prediction, Jackknife, hierarchical Bayes

\begin{abstract}
Poverty alleviation policy in the government of the president of Ir. H. Joko Widodo is carried out through four key strategies, one of which is the empowerment of poor community groups. The availability of information on poverty is very minimum, whereas in order to implement the policy strategy it should be started with the smallest community group, namely the village community. In order to obtain poverty information at the village level, this study applies a small area estimation method as a result of the ineffective direct estimation for a small area. Commonly used small area estimation methods are the empirical best linear unbiased prediction (EBLUP), empirical Bayes (EB), and the hierarchical Bayes $(H B)$. The results obtained on the estimation of small areas at the village level in Bali Province show that the estimated proportion of poor households at the village level in Bali Province is between 0.00423 and 0.03910 and the mean square error value is between 0.0013 and 0, 1291 is obtained through the Bayes hierarchical method, then for the Bayes empirical method, the estimated proportion of poor households is between 0.00423 and 0.03909 and the mean square error value is between 0.0011 and 0.1288 and the empirical best linear unbiased prediction method is obtained. the estimated proportion of poor households is between 0.00425 and 0.03910 and the mean square error value is between 0.00010 and 0.1291. In general, the mean square error values are in the same range. So that the three prediction methods cannot be concluded which is better than one another.
\end{abstract}

Keywords: Empirical Bayes, empirical best linear unbiased prediction, Jackknife, hierarchical Bayes, small area

Article info:

Submitted: $05^{\text {th }}$ November 2020 Accepted: $05^{\text {th }}$ April 2021

How to cite this article:

I. K. G Sukarsa and I. G. K Gandhiadi, PENDUGAAN PROPORSI RUMAH TANGGA MISKIN TINGKAT DESA DI PROVINSI BALI DENGAN METODE EMPIRICAL BEST LINEAR UNBIASED PREDICTION DAN BAYESIAN", BAREKENG: J. Il. Mat. \& Ter., vol. 15, no. 02, pp. 215-222, Jun. 2021.

This work is licensed under a Creative Commons Attribution-ShareAlike 4.0 International License. Copyright @ 2021 I K. G Sukarsa, I G. K Gandhiadi 


\section{PENDAHULUAN}

Kemiskinan merupakan salah satu masalah yang ingin dihapuskan dalam pemerintahan Presiden Ir. H. Joko Widodo. Pengentasan kemiskinan pada masa pemerintahan beliau dilakukan dengan empat strategi utama yakni memperbaiki program perlindungan sosial, meningkatkan akses terhadap pelayanan dasar, pemberdayaan kelompok masyarakat miskin, dan pembangunan inklusif [1]. Dalam memberdayakan kelompok masyarakat miskin, pemerintah tidak bisa memperlakukan penduduk miksin sebagai objek pembangunan sehingga upaya-upaya yang dilakukan ditinjau dari keseharian seperti pemberian pelatihan mengenai digital marketing dan pelatihan budidaya untuk bersaing di era ekonomi modern. Tujuan dari pemberdayaan ini adalah agar masyarakat tidak jatuh ke kembali dalam kemiskinan. Namun salah satu hal yang menjadi kendala adalah pemerintah haruslah mengetahui jumlah penduduk miskin yang ada bahkan hingga pada tingkatan terkecil. Untuk mengetahui informasi penduduk miskin salah satunya dapat berasal dari proporsi rumah tangga miskin di setiap desa/kelurahan. Rumah tangga miskin menurut Badan Pusat Statistik adalah rumah tangga dengan kondisi yang berada di bawah garis kemiskinan dan jika suatu rumah tangga miskin tidak dapat memenuhi kebutuhan primernya maka berada di bawah garis kemiskinan. Dengan melakukan penelitian mengenai kemiskinan pada tingkat terendah, hasil yang diperoleh akan menjadi informasi yang dapat digunakan untuk menyusun kebijakan yang dapat mengurangi tingkat kemiskinan di suatu daerah.

Untuk menduga proporsi rumah tangga miskin di suatu daerah pada tingkat area kecil salah satunya dapat digunakan pendugaan area kecil [2]. Pentingnya pendugaan area kecil tidak terlepas dari peran survei dan sensus yang hanya menjangkau area-area besar, sehingga sebuah pendugaan alternatif diperlukan dalan menduga parameter pada area kecil [2]. Pendugaan area kecil merupakan suatu teknik pendugaan yang digunakan untuk mengestimasi parameter pada area kecil dengan menggunakan bantuan variabel penyerta [3]. Area kecil dapat dimaknai dalam dua hal. Pertama area kecil dapat bermakna sebagai wilayah dengan jumlah sampel yang tidak memadai seperti di tingkat desa ataupun kecamatan dan yang kedua area kecil dapat bermakna sebagai indikator atau amatan kecil pada suatu daerah seperti proporsi rumah tangga miskin, proporsi hidup sehat, laju penyebaran penyakit, dan lain-lain [4].

Pendugaan area kecil memiliki tiga metode yang umum digunakan antara lain yaitu metode empirical best linear unbiased prediction (EBLUP), metode empirical Bayes (EB), dan metode hierarchical Bayes (HB) [3]. Ketiga metode ini merupakan metode yang berbasis statistik [5]. Metode EBLUP memiliki kelebihan yaitu proses perhitungan relatif mudah tanpa memerlukan proses numerik, namun memiliki kekurangan pada hasil pendugaan yang tidak lebih baik dibandingkan dua metode lainnya. Metode EB dan HB yang keduanya merupakan metode berbasis statistika Bayes memilki kelebihan pada hasil pendugaan yang lebih baik karena berdasar pada informasi awal (prior) [4] yang tersedia namun memiliki kekurangan pada proses perhitungan yang tidak sederhana [9]. Penelitian ini akan berfokus pada penggunakan metode EBLUP, EB, dan HB untuk menunjukkan hasil perbandingan dugaan dengan metode-metode dalam pendugaan area kecil.

\section{METODE PENELITIAN}

Penelitian ini menggunakan data variabel penyerta berupa jumlah rumah tangga miskin sebagai variabel respon $(Y)$ dengan variabel-variabel prediktornya antara lain jumlah penduduk di masing-masing desa/kelurahan $\left(X_{1}\right)$ [5] yang diperoleh dari hasil Survei Penduduk Antar Sensus (SUPAS) tahun 2015 dan profil desa, jumlah rumah tangga pengguna air PDAM $\left(X_{2}\right)$ [6], dan jumlah rumah tangga pengguna listrik PLN $\left(X_{3}\right)$ [5] yang diperoleh dari hasil Survei Sosial Ekonomi Nasional (SUSENAS) tahun 2018. Seluruh variabel penyerta yang digunakan merupakan data Provinsi Bali. Penelitian ini merupakan pengembangan dari penelitian yang pernah dilakukan di Kabupaten Klungkung oleh Ariwijayanthi [7].

Langkah-langkah yang dilakukan dalam penelitian ini dimulai dengan melakukan statistik deskriptif terkait dengan variabel penyerta yang dimiliki kemudian dilanjutkan dengan melakukan pendugaan dengan menggunakan metode EBLUP, EB, dan HB serta membandingkan keakuratan pendugaan yang digambarkan melalui nilai mean square error (MSE). Nilai MSE dalam pendugaan area kecil diperoleh dengan metode Jackknife yang digunakan untuk mengoreksi bias pada penduga [8]. 


\subsection{Langkah Analisis}

1. Melakukan pendugaan proporsi rumah tangga miskin dengan menggunakan metode empirical best linear unbiased prediction dan nilai mean square error dengan model EBLUP

$\hat{\mu}^{H}=t(\delta)=t(\hat{\delta}(y))=l^{T} \hat{\beta}+m^{T} v$

$y=x \beta+e$

dengan $\hat{\mu}^{H}=t(\delta)$ adalah parameter proporsi rumah tanggan miskin yang diduga dan nilai $\operatorname{Var}(\delta)$ diduga menggunakan $\operatorname{Var}(\hat{\delta}(y))$ yang merupakan penduga tak bias [3] dengan $\delta$ merupakan parameter penyerta yang diduga menggunakan sampel amatan $y$. Dalam dugaan parameter regresi $\hat{\beta}$ digunakan metode maximum likelihood yang diasumsikan berdistribusi normal.

2. Melakukan estimasi nilai mean square error dari metode EBLUP dengan nilai error metode EBLUP diperoleh dari

$t(\delta)-\mu=\hat{\mu}^{H}-\mu$

dan

$\operatorname{MSE}(t(\delta)) \approx g_{1}(\hat{\delta})+g_{2}(\hat{\delta})$

namun karena nilai $g_{i}(\hat{\delta})$ bias dengan $g_{i}(\hat{\delta})$ diperlukan metode yang dapat mengoreksi bias tersebut, sehingga dalam menduga nilai mean square error digunakan metode Jackknife [8]

$M S E_{\text {jack }}\left(\hat{\mu}^{H}\right)=M_{1 i}+M_{2 i}$

dengan $M_{1 i}=g_{1 i}\left(\hat{\beta}, y_{i}\right)-\frac{m-1}{m} \sum_{i=1}^{m}\left[g_{1 i}\left(\operatorname{Var}(\delta)_{i-1}\right)-g_{1 i}\left(\operatorname{Var}(\delta)_{i}\right)\right]$

dan $M_{2 i}=\frac{m-1}{m} \sum_{i=1}^{m}\left[\hat{\mu}_{i-1}^{H}-\hat{\mu}_{i}^{H}\right]^{2}$

3. Melakukan pendugaan proporsi rumah tangga miskin dengan metode empirical Bayes kemudian menentukan dugaan mean square error dengan model EB

$\widehat{\theta}_{l}^{E B}=\widehat{\gamma}_{l} \widehat{\theta}_{l}+\left(1-\widehat{\gamma}_{l}\right) \widehat{\theta}_{l}$

dengan asumsi prior $y \sim N\left(0, \sigma_{0}^{2}\right)$ sehingga menghasilkan posterior yang $\theta \sim N\left(0, \sigma^{2}+\sigma_{0}^{2}\right)$ melalui statistika Bayes

dengan $\widehat{\gamma}_{l}=\frac{\widehat{\sigma}_{0 i}^{2}}{\widehat{\sigma}_{0 i}^{2}+\widehat{\sigma}_{i}^{2}}$

$\operatorname{dan} \widehat{\theta}_{l}=x \hat{\beta}$

$\hat{\theta}_{i}^{E B}$ : parameter dugaan empirical Bayes ke- $i$

$\hat{\theta}_{i}:$ parameter dugaan ke- $i$

4. Melakukan estimasi nilai mean square error dari metode EB dengan nilai error metode EB diperoleh dengan metode Jackknife:

$\operatorname{MSE}_{\text {jack }}\left(\widehat{\theta_{l}^{E B}}\right)=M_{1 i}+M_{2 i}$

dengan $M_{1 i}=g_{1 i}\left(\sigma_{0}^{2}, \sigma^{2}, y\right)-\frac{m-1}{m} \sum_{i=1}^{m}\left[g_{1 i}\left(\sigma^{2}\right)-g_{1 i}\left(\sigma^{2}\right)\right]$

$\operatorname{dan} M_{2 i}=\frac{m-1}{m} \sum_{i=1}^{m}\left[\hat{\theta}_{i_{i}-i}^{E B}-\hat{\theta}_{i}^{E B}\right]^{2}$

5. Melakukan pendugaan proporsi rumah tangga miskin dengan metode hierrarchical Bayes kemudian menentukan dugaan mean square error dengan model HB

$\widehat{\phi}_{l}^{H B}=\widehat{\gamma}_{l} \widehat{\theta}_{l}+\left(1-\widehat{\gamma}_{l}\right) \widehat{\theta}_{l}$

dengan asumsi prior $y \sim N\left(0, \sigma^{2}\right)$ sehingga menghasilkan posterior yang $\theta \sim N\left(0, \sigma^{2}+\psi^{2}\right)$ melalui simulasi monte carlo 
dengan $\widehat{\gamma_{l}}=\frac{\widehat{\sigma_{l}^{2}}}{{\widehat{\sigma_{l}}}^{2}+{\widehat{\psi_{l}}}^{2}}$

dan $\widehat{\theta}_{l}=x \hat{\beta}$

$\widehat{\phi}_{l}{ }^{H B}$ : parameter dugaan hierarchical Bayes ke-i

$\hat{\theta}_{i}$ : parameter dugaan ke- $i$

6. Menggunakan hasil pendugaan dengan metode terbaik yang dipilih berdasarkan perbandingan nilai mean square error untuk memberi pertimbangan dalam pengambilan keputusan yang dilakukan.

$$
\begin{aligned}
& \operatorname{MSE}_{\text {jack }}\left(\widehat{\phi}_{l}^{H B}\right)=M_{1 i}+M_{2 i} \\
& \text { dengan } M_{1 i}=M_{1 i}=g_{1 i}\left(\sigma^{2}, \psi^{2}, y\right)-\frac{m-1}{m} \sum_{i=1}^{m}\left[g_{1 i}\left(\psi^{2}\right)-g_{1 i}\left(\psi^{2}\right)\right] \\
& \text { dan } M_{2 i}=\frac{m-1}{m} \sum_{i=1}^{m}\left[\hat{\phi}_{i-1}{ }^{H B}-\hat{\phi}_{i}^{H B}\right]^{2}
\end{aligned}
$$

\section{HASIL DAN PEMBAHASAN}

\subsection{Pendugaan Area Kecil Metode EBLUP}

Pendugaan proporsi rumah tangga miskin di Provinsi Bali dengan data penyerta jumlah penduduk di masing-masing desa/kelurahan $\left(X_{1}\right)$, jumlah rumah tangga pengguna air PDAM $\left(X_{2}\right)$, dan jumlah rumah tangga pengguna listrik PLN $\left(X_{3}\right)$ dengan menggunakan metode EBLUP menghasilkan model dugaan:

$$
\hat{\mu}^{H}=13,57-0,01 X_{1}-0,26 X_{2}-0,32 X_{3}
$$

\begin{tabular}{|c|c|c|c|c|c|c|c|c|c|c|c|}
\hline \multirow{2}{*}{$\begin{array}{l}\text { Kab/ } \\
\text { Kota }\end{array}$} & \multirow[t]{2}{*}{ Desa } & \multicolumn{2}{|c|}{ EBLUP } & \multirow{2}{*}{$\begin{array}{l}\text { Kab/ } \\
\text { Kota }\end{array}$} & \multirow[t]{2}{*}{ Desa } & \multicolumn{2}{|c|}{ EBLUP } & \multirow{2}{*}{$\begin{array}{l}\text { Kab/ } \\
\text { Kota }\end{array}$} & \multirow[t]{2}{*}{ Desa } & \multicolumn{2}{|c|}{ EBLUP } \\
\hline & & Est & MSE & & & Est & MSE & & & Est & MSE \\
\hline \multirow{7}{*}{$\begin{array}{c}\mathrm{J} \\
\mathrm{E} \\
\mathrm{M} \\
\mathrm{B} \\
\mathrm{R} \\
\mathrm{A} \\
\mathrm{N} \\
\mathrm{A}\end{array}$} & $\begin{array}{c}\text { Mendoyo } \\
\text { Dauh Tukad }\end{array}$ & 0.02476 & 0.00472 & \multicolumn{2}{|c|}{$\begin{array}{c}\mathrm{G} \\
\mathrm{I}\end{array}$} & 0.01746 & 0.01522 & \multirow{2}{*}{$\begin{array}{l}\mathrm{K} \\
\mathrm{A} \\
\mathrm{R}\end{array}$} & Bebandem & 0.01578 & 0.01019 \\
\hline & $\begin{array}{c}\text { Tegal } \\
\text { Cangkring } \\
\end{array}$ & 0.02472 & 0.03572 & \multirow{4}{*}{$\begin{array}{l}\mathrm{A} \\
\mathrm{N} \\
\mathrm{Y} \\
\mathrm{A} \\
\mathrm{R}\end{array}$} & Sebatu & 0.01745 & 0.01078 & & Sebudi & 0.01560 & 0.02039 \\
\hline & Penyaringan & 0.02464 & 0.01508 & & Keliki & 0.01742 & 0.01237 & \multirow[b]{2}{*}{$\mathrm{N}$} & Tista & 0.01529 & 0.02514 \\
\hline & Ekasari & 0.01337 & 0.01197 & & Tegallalang & 0.00870 & 0.01366 & & Purwakerti & 0.00820 & 0.00924 \\
\hline & $\begin{array}{c}\text { Yeh Embang } \\
\text { Kangin }\end{array}$ & 0.01336 & 0.02059 & & Sukawati & 0.00866 & 0.01334 & $\begin{array}{l}\mathrm{G} \\
\mathrm{A}\end{array}$ & Ababi & 0.00819 & 0.00753 \\
\hline & \multirow[t]{2}{*}{ Perancak } & & & & Ubud & & & $\begin{array}{l}\mathrm{S} \\
\mathrm{E}\end{array}$ & \multirow[t]{2}{*}{ Bugbug } & & \\
\hline & & 0.01332 & 0.02518 & & & 0.00865 & 0.01178 & M & & 0.00819 & 0.00797 \\
\hline \multirow{6}{*}{$\begin{array}{l}\mathrm{T} \\
\mathrm{A} \\
\mathrm{B} \\
\mathrm{A} \\
\mathrm{N} \\
\mathrm{A} \\
\mathrm{N}\end{array}$} & Sanda & 0.00923 & 0.00660 & $\mathrm{~K}$ & Pikat & 0.02025 & 0.05230 & \multirow{3}{*}{$\begin{array}{l}\mathrm{B} \\
\mathrm{U} \\
\mathrm{L} \\
\mathrm{E} \\
\mathrm{L}\end{array}$} & $\begin{array}{c}\text { Poh } \\
\text { Bergong } \\
\end{array}$ & 0.00814 & 0.00636 \\
\hline & $\begin{array}{l}\text { Pangkung } \\
\text { Tibah }\end{array}$ & 0.00922 & 0.00808 & U & Tangkas & 0.02024 & 0.01477 & & Tinga-tinga & 0.00813 & 0.01295 \\
\hline & $\begin{array}{c}\text { Baturiti } \\
\text { (Baturiti) } \\
\end{array}$ & 0.00917 & 0.00140 & $\begin{array}{l}\mathrm{N} \\
\mathrm{G}\end{array}$ & Jumpai & 0.02017 & 0.00642 & & $\begin{array}{c}\text { Pangkung } \\
\text { Paruk }\end{array}$ & 0.00801 & 0.00867 \\
\hline & Jatiluwih & 0.00462 & 0.00364 & $\begin{array}{l}\mathrm{K} \\
\mathrm{U}\end{array}$ & $\begin{array}{c}\text { Semarapura } \\
\text { Klod } \\
\text { Kangin } \\
\end{array}$ & 0.01061 & 0.01798 & $\begin{array}{l}\mathrm{E} \\
\mathrm{N}\end{array}$ & Sukasada & 0.00425 & 0.00149 \\
\hline & Penatahan & 0.00460 & 0.01908 & $\mathrm{~N}$ & Pesinggahan & 0.01059 & 0.03049 & G & Sekumpul & 0.00425 & 0.01434 \\
\hline & Candikuning & 0.00459 & 0.00403 & G & $\begin{array}{c}\text { Semarapura } \\
\text { Klod }\end{array}$ & 0.01056 & 0.03373 & & Pancasari & 0.00424 & 0.00463 \\
\hline $\begin{array}{l}\mathrm{B} \\
\mathrm{A}\end{array}$ & $\begin{array}{c}\text { Dauh Yeh } \\
\text { Cani }\end{array}$ & 0.01937 & 0.01979 & $\begin{array}{l}\mathrm{B} \\
\mathrm{A}\end{array}$ & Binyan & 0.01710 & 0.01271 & $\begin{array}{l}\mathrm{D} \\
\mathrm{E}\end{array}$ & Pemogan & 0.03916 & 0.02433 \\
\hline D & Getasan & 0.01933 & 0.03321 & G & $\begin{array}{l}\text { Bayung } \\
\text { Gede }\end{array}$ & 0.01710 & 0.02864 & $\begin{array}{l}\mathrm{N} \\
\mathrm{P}\end{array}$ & $\begin{array}{c}\text { Padang } \\
\text { Sambian } \\
\text { Kaja }\end{array}$ & 0.03915 & 0.01202 \\
\hline $\mathrm{N}$ & Mengwitani & 0.01917 & 0.00817 & $\begin{array}{l}\mathrm{L} \\
\mathrm{I}\end{array}$ & Mengani & 0.01710 & 0.00260 & $\begin{array}{l}\mathrm{A} \\
\mathrm{S}\end{array}$ & $\begin{array}{c}\text { Peguyangan } \\
\text { Kangin } \\
\end{array}$ & 0.03905 & 0.03565 \\
\hline & Jimbaran & 0.00972 & 0.00633 & & Taman Bali & 0.00856 & 0.01545 & A & Sanur & 0.02916 & 0.02022 \\
\hline & Kuta & 0.00959 & 0.01494 & & Kubu & 0.00854 & 0.01412 & $\begin{array}{l}A \\
\mathrm{R}\end{array}$ & $\begin{array}{c}\text { Dauh Puri } \\
\text { Klod }\end{array}$ & 0.02873 & 0.04810 \\
\hline & Legian & 0.00950 & 0.02205 & & Kintamani & 0.00854 & 0.01354 & & Renon & 0.02872 & 0.03474 \\
\hline
\end{tabular}

Tabel 1. Hasil Pendugaan Proporsi Rumah Tangga Miskin Terbesar dan Terkecil di 3 Desa dengan empirical best linear unbiased prediction 
Pendugaan area kecil menggunakan metode EBLUP menghasilkan nilai dugaan proporsi rumah tangga miskin di tingkat desa dengan Tabel 1 menunjukkan dugaan terbesar dan terkecil pada 3 desa di masing-masing kabupaten. Nilai dugaan proporsi rumah tangga miskin di tingkat desa di Provinsi Bali berkisar antara 0,00423 dan 0,03916 dengan nilai mean square error sekitar 0,0013 sampai 0,1281 untuk seluruh Provinsi Bali.

\subsection{Pendugaan Area Kecil Metode EB}

Pendugaan proporsi rumah tangga miskin di Provinsi Bali dengan data penyerta jumlah penduduk di masing-masing desa/kelurahan $\left(X_{1}\right)$, jumlah rumah tangga pengguna air PDAM $\left(X_{2}\right)$, dan jumlah rumah tangga pengguna listrik PLN $\left(X_{3}\right)$ dengan menggunakan metode EB menghasilkan model dugaan:

$$
\begin{aligned}
& \widehat{\theta}_{l}^{E B}=\left(\frac{1270,9}{1270,9+1931,321}\right) \widehat{\theta}_{l}+\left(1-\frac{1270,9}{1270,9+1931,321}\right) \widehat{\theta}_{l} \\
& \widehat{\theta}_{l}=13,536-0,015 X_{1}-0,27 X_{2}-0,32 X_{3}
\end{aligned}
$$

Tabel 2. Hasil Pendugaan Proporsi Rumah Tangga Miskin Terbesar dan Terkecil

\begin{tabular}{|c|c|c|c|c|c|c|c|c|c|c|c|}
\hline \multirow{2}{*}{$\begin{array}{l}\text { Kab./ } \\
\text { Kota }\end{array}$} & \multirow[t]{2}{*}{ Desa } & \multicolumn{2}{|c|}{ EB } & \multirow{2}{*}{$\begin{array}{l}\text { Kab/ } \\
\text { Kota }\end{array}$} & \multirow[t]{2}{*}{ Desa } & \multicolumn{2}{|c|}{ EB } & \multirow{2}{*}{$\begin{array}{l}\text { Kab./ } \\
\text { Kota }\end{array}$} & \multirow[t]{2}{*}{ Desa } & \multicolumn{2}{|c|}{ EB } \\
\hline & & Est & MSE & & & Est & MSE & & & Est & MSE \\
\hline \multirow{7}{*}{$\begin{array}{c}\mathrm{J} \\
\mathrm{E} \\
\mathrm{M} \\
\mathrm{B} \\
\mathrm{R} \\
\mathrm{A} \\
\mathrm{N} \\
\mathrm{A}\end{array}$} & $\begin{array}{c}\text { Mendoyo } \\
\text { Dauh Tukad }\end{array}$ & 0.02470 & 0.00293 & \multirow{7}{*}{$\begin{array}{l}\text { G } \\
\text { I } \\
\text { A } \\
\text { N } \\
Y \\
\text { A } \\
\text { R }\end{array}$} & Buahan & 0.01738 & 0.01523 & \multirow{6}{*}{$\begin{array}{l}\mathrm{K} \\
\mathrm{A}\end{array}$} & Bebandem & 0.01573 & 0.01025 \\
\hline & $\begin{array}{c}\text { Tegal } \\
\text { Cangkring }\end{array}$ & 0.02483 & 0.03641 & & Sebatu & 0.01749 & 0.01078 & & Sebudi & 0.01557 & 0.02041 \\
\hline & Penyaringan & 0.02464 & 0.01528 & & Keliki & 0.01733 & 0.01224 & & Tista & 0.01525 & 0.02521 \\
\hline & Ekasari & 0.01353 & 0.01264 & & Tegallalang & 0.00864 & 0.01367 & & Purwakerti & 0.00830 & 0.00915 \\
\hline & Yeh & & & & \multirow[b]{2}{*}{ Sukawati } & & & & \multirow[b]{2}{*}{ Ababi } & & \\
\hline & $\begin{array}{c}\text { Embang } \\
\text { Kangin }\end{array}$ & 0.01355 & 0.02035 & & & 0.00876 & 0.01332 & & & 0.00823 & 0.00757 \\
\hline & Perancak & 0.01340 & 0.02597 & & Ubud & 0.00858 & 0.01 & $\begin{array}{l}\mathrm{S} \\
\mathrm{E} \\
\mathrm{M}\end{array}$ & Bugbug & & 0.00797 \\
\hline \multirow{6}{*}{$\begin{array}{l}\mathrm{T} \\
\mathrm{A} \\
\mathrm{B} \\
\mathrm{A} \\
\mathrm{N} \\
\mathrm{A} \\
\mathrm{N}\end{array}$} & Sanda & 0.00920 & 0.00656 & \multirow{6}{*}{$\begin{array}{l}\mathrm{K} \\
\mathrm{L} \\
\mathrm{U} \\
\mathrm{N} \\
\mathrm{G} \\
\mathrm{K} \\
\mathrm{U} \\
\mathrm{N} \\
\mathrm{G}\end{array}$} & Pikat & 0.02020 & 0.05264 & \multirow{6}{*}{$\begin{array}{l}B \\
U \\
L \\
E \\
L \\
E \\
N \\
G\end{array}$} & $\begin{array}{c}\text { Poh } \\
\text { Bergong }\end{array}$ & 0.00810 & 0.00632 \\
\hline & $\begin{array}{l}\text { Pangkung } \\
\text { Tibah }\end{array}$ & 0.00923 & 0.00804 & & Tangkas & 0.02019 & 0.01483 & & Tinga-tinga & 0.00810 & 0.01299 \\
\hline & $\begin{array}{c}\text { Baturiti } \\
\text { (Baturiti) }\end{array}$ & 0.00913 & 0.00136 & & Jumpai & 0.02017 & 0.00621 & & $\begin{array}{c}\text { Pangkung } \\
\text { Paruk }\end{array}$ & 0.00803 & 0.00872 \\
\hline & Jatiluwih & 0.00468 & 0.00365 & & $\begin{array}{c}\text { Semarapura } \\
\text { Klod } \\
\text { Kangin }\end{array}$ & 0.01069 & 0.01806 & & Sukasada & 0.00423 & 0.00145 \\
\hline & Penatahan & 0.00460 & 0.01925 & & Pesinggahan & 0.01068 & 0.03057 & & Sekumpul & 0.00427 & 0.01441 \\
\hline & Candikuning & 0.00463 & 0.00394 & & $\begin{array}{c}\text { Semarapura } \\
\text { Klod }\end{array}$ & 0.01048 & 0.03401 & & Pancasari & 0.00424 & 0.00459 \\
\hline $\begin{array}{l}\mathrm{B} \\
\mathrm{A}\end{array}$ & $\begin{array}{c}\text { Dauh Yeh } \\
\text { Cani }\end{array}$ & 0.01933 & 0.01979 & $\begin{array}{l}\mathrm{B} \\
\mathrm{A}\end{array}$ & Binyan & 0.01718 & 0.01269 & $\begin{array}{l}\mathrm{D} \\
\mathrm{E}\end{array}$ & Pemogan & 0.03907 & 0.02431 \\
\hline D & Getasan & 0.01939 & 0.03337 & $\begin{array}{l}\mathrm{N} \\
\mathrm{G}\end{array}$ & $\begin{array}{l}\text { Bayung } \\
\text { Gede }\end{array}$ & 0.01705 & 0.02873 & $\begin{array}{l}\mathrm{N} \\
\mathrm{P}\end{array}$ & $\begin{array}{c}\text { Padang } \\
\text { Sambian } \\
\text { Kaja } \\
\end{array}$ & 0.03894 & 0.01193 \\
\hline $\begin{array}{l}\mathrm{N} \\
\mathrm{G}\end{array}$ & Mengwitani & 0.01923 & 0.00800 & $\begin{array}{l}\mathrm{L} \\
\mathrm{I}\end{array}$ & Mengani & 0.01705 & 0.00241 & $\begin{array}{l}\text { A } \\
\text { S }\end{array}$ & $\begin{array}{c}\text { Peguyangan } \\
\text { Kangin }\end{array}$ & 0.03922 & 0.03586 \\
\hline & Jimbaran & 0.00971 & 0.00623 & & Taman Bali & 0.00858 & 0.01540 & A & Sanur & 0.02899 & 0.02039 \\
\hline & Kuta & 0.00968 & 0.01497 & & Kubu & 0.00849 & 0.01405 & $\begin{array}{l}\mathrm{A} \\
\mathrm{R}\end{array}$ & $\begin{array}{l}\text { Dauh Puri } \\
\text { Klod }\end{array}$ & 0.02899 & 0.04798 \\
\hline & Legian & 0.00961 & 0.02214 & & Kintamani & 0.00861 & 0.01356 & & Renon & 0.02875 & 0.03449 \\
\hline
\end{tabular}
di 3 Desa dengan Empirical Bayes

Pendugaan area kecil menggunakan metode EB menghasilkan nilai dugaan proporsi rumah tangga miskin di tingkat desa dengan Tabel 2 menunjukkan dugaan terbesar dan terkecil pada 3 desa di masingmasing kabupaten. Nilai dugaan proporsi rumah tangga miskin di tingkat desa di Provinsi Bali berkisar antara 0,00423 dan 0,03909 dengan nilai mean square error sekitar 0,0011 sampai 0,1288 untuk seluruh Provinsi Bali. 


\subsection{Pendugaan Area Kecil Metode HB}

Pendugaan proporsi rumah tangga miskin di Provinsi Bali dengan data penyerta jumlah penduduk di masing-masing desa/kelurahan $\left(X_{1}\right)$, jumlah rumah tangga pengguna air PDAM $\left(X_{2}\right)$, dan jumlah rumah tangga pengguna listrik PLN $\left(X_{3}\right)$ dengan menggunakan metode HB menghasilkan model dugaan:

$$
\begin{aligned}
& \widehat{\theta}_{l}^{E B}=\left(\frac{1270,921}{1270,921+1931,321}\right) \widehat{\theta}_{l}+\left(1-\frac{1270,921}{1270,921+1931,321}\right) \widehat{\theta}_{l} \\
& \widehat{\theta}_{l}=13,537-0,015 X_{1}-0,267 X_{2}-0,3206 X_{3}
\end{aligned}
$$

Tabel 3. Hasil Pendugaan Proporsi Rumah Tangga Miskin Terbesar dan Terkecil

\begin{tabular}{|c|c|c|c|c|c|c|c|c|c|c|c|}
\hline \multirow{2}{*}{$\begin{array}{l}\text { Kab/ } \\
\text { Kota }\end{array}$} & \multirow[t]{2}{*}{ Desa } & \multicolumn{2}{|c|}{ HB } & \multirow{2}{*}{$\begin{array}{l}\text { Kab/ } \\
\text { Kota }\end{array}$} & \multirow[t]{2}{*}{ Desa } & \multicolumn{2}{|c|}{ HB } & \multirow{2}{*}{$\begin{array}{l}\text { Kab/ } \\
\text { Kota }\end{array}$} & \multirow[t]{2}{*}{ Desa } & \multicolumn{2}{|c|}{ HB } \\
\hline & & Est & MSE & & & Est & MSE & & & Est & MSE \\
\hline \multirow{2}{*}{$\begin{array}{c}\mathrm{J} \\
\mathrm{E} \\
\mathrm{M}\end{array}$} & $\begin{array}{c}\text { Mendoyo } \\
\text { Dauh Tukad }\end{array}$ & 0.02479 & 0.00087 & \multirow{6}{*}{$\begin{array}{l}\mathrm{G} \\
\mathrm{I} \\
\mathrm{A} \\
\mathrm{N} \\
\mathrm{Y} \\
\mathrm{A} \\
\mathrm{R}\end{array}$} & Buahan & 0.01739 & 0.01520 & \multirow{6}{*}{$\begin{array}{l}\mathrm{K} \\
\mathrm{A} \\
\mathrm{R} \\
\mathrm{A} \\
\mathrm{N} \\
\mathrm{G} \\
\mathrm{A} \\
\mathrm{S} \\
\mathrm{E} \\
\mathrm{M}\end{array}$} & Bebandem & 0.01564 & 0.01017 \\
\hline & $\begin{array}{c}\text { Tegal } \\
\text { Cangkring } \\
\end{array}$ & 0.02487 & 0.03806 & & Sebatu & 0.01739 & 0.01076 & & Sebudi & 0.01560 & 0.02040 \\
\hline \multirow{4}{*}{$\begin{array}{l}\mathrm{B} \\
\mathrm{R} \\
\mathrm{A} \\
\mathrm{N} \\
\mathrm{A}\end{array}$} & Penyaringan & 0.02446 & 0.01553 & & Keliki & 0.01742 & 0.01228 & & Tista & 0.01530 & 0.02522 \\
\hline & Ekasari & 0.01356 & 0.01218 & & Tegallalang & 0.00866 & 0.01373 & & Purwakerti & 0.00835 & 0.00916 \\
\hline & $\begin{array}{c}\text { Yeh Embang } \\
\text { Kangin }\end{array}$ & 0.01352 & 0.02007 & & Sukawati & 0.00890 & 0.01328 & & Ababi & 0.00827 & 0.00749 \\
\hline & Perancak & 0.01358 & 0.02571 & & Ubud & 0.00868 & 0.01167 & & & 0.00814 & 0.00800 \\
\hline \multirow{6}{*}{$\begin{array}{l}\mathrm{T} \\
\mathrm{A} \\
\mathrm{B} \\
\mathrm{A} \\
\mathrm{N} \\
\mathrm{A} \\
\mathrm{N}\end{array}$} & Sanda & 0.00921 & 0.00661 & \multirow{6}{*}{$\begin{array}{l}\text { K } \\
L \\
U \\
N \\
G \\
K \\
U \\
N \\
G \\
\end{array}$} & Pikat & 0.02022 & 0.05280 & \multirow{6}{*}{$\begin{array}{l}\text { B } \\
\mathrm{U} \\
\mathrm{L} \\
\mathrm{E} \\
\mathrm{L} \\
\mathrm{E} \\
\mathrm{N} \\
\mathrm{G}\end{array}$} & $\begin{array}{c}\text { Poh } \\
\text { Bergong }\end{array}$ & 0.00805 & 0.00630 \\
\hline & $\begin{array}{c}\text { Pangkung } \\
\text { Tibah }\end{array}$ & 0.00921 & 0.00808 & & Tangkas & 0.02013 & 0.01483 & & Tinga-tinga & 0.00812 & 0.01304 \\
\hline & $\begin{array}{c}\text { Baturiti } \\
\text { (Baturiti) }\end{array}$ & 0.00915 & 0.00130 & & Jumpai & 0.02011 & 0.00621 & & $\begin{array}{c}\text { Pangkung } \\
\text { Paruk }\end{array}$ & 0.00799 & 0.00871 \\
\hline & Jatiluwih & 0.00472 & 0.00359 & & $\begin{array}{c}\text { Semarapura } \\
\text { Klod Kangin }\end{array}$ & 0.01085 & 0.01808 & & Sukasada & 0.00430 & 0.00144 \\
\hline & Penatahan & 0.00464 & 0.01934 & & Pesinggahan & 0.01067 & 0.03075 & & Sekumpul & 0.00432 & 0.01445 \\
\hline & Candikuning & 0.00471 & 0.00387 & & $\begin{array}{c}\text { Semarapura } \\
\text { Klod }\end{array}$ & 0.01060 & 0.03411 & & Pancasari & 0.00425 & 0.00461 \\
\hline \multirow{6}{*}{$\begin{array}{l}\mathrm{B} \\
\mathrm{A} \\
\mathrm{D} \\
\mathrm{U} \\
\mathrm{N} \\
\mathrm{G}\end{array}$} & $\begin{array}{l}\text { Dauh Yeh } \\
\text { Cani }\end{array}$ & 0.01942 & 0.01977 & \multirow{6}{*}{$\begin{array}{l}\text { B } \\
A \\
N \\
G \\
L \\
\text { I }\end{array}$} & Binyan & 0.01722 & 0.01262 & \multirow{6}{*}{$\begin{array}{l}\mathrm{D} \\
\mathrm{E} \\
\mathrm{N} \\
\mathrm{P} \\
\mathrm{A} \\
\mathrm{S} \\
\mathrm{A} \\
\mathrm{R}\end{array}$} & Pemogan & 0.03908 & 0.02408 \\
\hline & Getasan & 0.01927 & 0.03343 & & $\begin{array}{l}\text { Bayung } \\
\text { Gede }\end{array}$ & 0.01710 & 0.02879 & & $\begin{array}{c}\text { Padang } \\
\text { Sambian } \\
\text { Kaja }\end{array}$ & 0.03910 & 0.01175 \\
\hline & Mengwitani & 0.01922 & 0.00798 & & Mengani & 0.01697 & 0.00225 & & $\begin{array}{l}\text { Peguyangan } \\
\text { Kangin }\end{array}$ & 0.03896 & 0.03589 \\
\hline & Jimbaran & 0.00977 & 0.00619 & & Taman Bali & 0.00865 & 0.01532 & & Sanur & 0.02896 & 0.02045 \\
\hline & Kuta & 0.00969 & 0.01488 & & Kubu & 0.00861 & 0.01404 & & $\begin{array}{c}\text { Dauh Puri } \\
\text { Klod }\end{array}$ & 0.02901 & 0.04807 \\
\hline & Legian & 0.00957 & 0.02215 & & Kintamani & 0.00856 & 0.01361 & & Renon & 0.02902 & 0.03444 \\
\hline
\end{tabular}
di 3 Desa dengan hierarchical Bayes

Pendugaan area kecil menggunakan metode HB menghasilkan nilai dugaan proporsi rumah tangga miskin di tingkat desa dengan Tabel 3 menunjukkan dugaan terbesar dan terkecil pada 3 desa di masingmasing kabupaten. Nilai dugaan proporsi rumah tangga miskin di tingkat desa di Provinsi Bali berkisar antara 0,00425 dan 0,03910 dengan nilai mean square error sekitar 0,0010 sampai 0,1294 untuk seluruh Provinsi Bali.

\subsection{Perbandingan Hasil Dugaan Ketiga Metode}

Melalui ketiga metode pendugaan, diperoleh masing-masing hasil dugaan proporsi rumah tangga miskin di masing-masing desa di Provinsi Bali yang tidak terlalu berbeda jika dilakukan pembulatan. Kemudian ketiga hasil pendugaan ini dibandingkan melalui nilai MSE yang diperoleh masing-masing pendugaan. Hasil yang diperoleh menunjukkan bahwa metode HB memiliki nilai MSE yang lebih kecil dibandingkan metode EB, dan metode EB memiliki nilai MSE yang lebih kecil dibandingkan metode EBLUP meskipun secara umum perbedaan nilai MSE ketiga metode tersebut sangatlah kecil. Oleh karena itu jika ketiga metode dibandingkan maka metode HB merupakan metode terbaik dalam pendugaan proporsi rumah tangga miskin di tingkat desa di Provinsi Bali. 


\section{KESIMPULAN}

Berdasarkan uraian dari hasil, diperoleh beberapa kesimpulan :

1. Pendugaan area kecil dengan metode hierarchical Bayes menghasilkan dugaan proporsi rumah tangga miskin di tingkat desa di Provinsi Bali antara 0,00423 sampai 0,03910.

2. Pendugaan area kecil dengan metode hierarchical Bayes menghasilkan nilai mean square error di antara 0,0013 sampai 0,1291 .

3. Pendugaan area kecil dengan metode empirical Bayes menghasilkan dugaan proporsi rumah tangga miskin di tingkat desa di Provinsi Bali antara 0,00423 sampai 0,03909.

4. Pendugaan area kecil dengan metode empirical Bayes menghasilkan nilai mean square error di antara 0,0011 sampai 0,1288 .

5. Pendugaan area kecil dengan metode empirical best linear unbiased prediction menghasilkan dugaan proporsi rumah tangga miskin di tingkat desa di Provinsi Bali antara 0,00425 sampai 0,03910 .

6. Pendugaan area kecil dengan metode empirical best linear unbiased prediction menghasilkan nilai mean square error di antara 0,00010 sampai 0,1291.

7. Dengan menggunakan data Provinsi Bali berupa jumlah penduduk di masing-masing desa/kelurahan $\left(X_{1}\right)$ yang diperoleh dari hasil Survei Penduduk Antar Sensus (SUPAS) tahun 2015 dan profil desa, jumlah rumah tangga pengguna air PDAM $\left(X_{2}\right)$, dan jumlah rumah tangga pengguna listrik PLN $\left(X_{3}\right)$ yang diperoleh dari hasil Survei Sosial Ekonomi Nasional (SUSENAS) tahun 2018 metode hierarchical Bayes menghasilkan dugaan proporsi rumah tangga miskin terbaik yang berada di antara 0,00423 dan 0,03910 dengan nilai mean square error terkecil yang berada di antara 0,0010 sampai 0,1291 .

\section{DAFTAR PUSTAKA}

[1] Murdiyana and Mulyana, "Analisis Kebijakan Pengentasan Kemiskinan di Indonesia," Jurnal Politik Pemerintahan, vol. 10, no. 1, pp. 73-96, 2017.

[2] D. Pfeffermann, "New Important Developments in Small Area Estimation," 2013.

[3] M. Ghosh and J. Rao, "Small Area Estimation: an Appraisal," Statistical Science Journal, vol. 9, pp. 55-76, 1994.

[4] N. T. Longford, Missing Data and Small-Area Estimation, Springer, 2005.

[5] M. Prastesi, Analysis of Poverty Data by Small Area Estimation, John Wiley \& Sons, 2016.

[6] J. Rao, Small Area Estimation, John Wiley and Sons. New York., 2003.

[7] A. Rahman and A. Harding, Small Area Estimation and Microsimulation Modelling, CRC Press, 2017.

[8] P. Congdon, Applied Bayesian Modelling, 2nd ed., New York: John Wiley \& Sons, 2014.

[9] B. J. Brewer, Introduction to Bayesian Statistics, 2017.

[10] I. Wulansari, "Pendugaan Statistik Area Kecil dengan Metode Hierarchical Bayes (HB) pada Data Respon Biner Menggunakan Gibbs Sampling," Tesis, 2015.

[11] M. Y. Darsyah, S. Iriyanto and I. Joko, "Small Area Estimation Untuk Pemetaan Kemiskinan di Kabupaten Demak," Jurnla Unimus, 2014.

[12] P. E. Arijayanthi, I. W. Sumarjaya and T. B. Oka, "Penerapan Metode Pendugaan Area Kecil (Small Area Estimation) pada Penentuan Proporsi Rumah Tangga Miskin di Kabupaten Klungkung," E-Jurnal Matematika, vol. 2, no. 3, pp. 35-39, 2013.

[13] A. Kurnia and K. A. Notodiputro, Penerapan Metode Jackknife Dalam Pendugaan Area Kecil, Bogor: Department of Statistics, IPB University, 2006. 
